\title{
RED-BELLIED WOODPECKER SIGHTING AT SALTCOATS
}

\section{J.R. JOWSEY, Box 400, Saltcoats, Saskatchewan. SOA 3RO}

Phone calls about unusual birds come to our house quite often at any time of the year. The clear description of the bird given by the caller caused my wife, Shirley, to relay one call to me with more curiosity than usual. She noted that the caller was Walter Brygider, whom we knew had more than an average interest in the natural world around him. Walter and his wife, Olga, felt quite certain that they had a Red-bellied Woodpecker in their farmyard.

Since Red-bellied Woodpeckers are not common anywhere in Canada, and since I had never seen one, I checked the field marks closely with Walter when I returned his call - top of head to nape of neck, bright red; sides of face and neck, off white, shading to reddish on abdomen; back and wings, black barred with white; size of a small flicker. Outer wings black with a white patch observed in flight. What else could it be?

By the time I got around to returning Walter's call, it was raining heavily and very windy, so we promised to visit them the next morning if the bird was still there.

Shirley and I then carefully worked over the descriptions and colour plates in our bird books for the Redbellied Woodpecker. We also noted that one sighting had occurred in Saskatchewan in 1959, and know well how closely bird sightings were checked by Margaret Belcher (Birds of Regina) and her cadre of birders.

Walter Brygider had a theory for us. The woodpecker, being like a flicker, had joined a group of flickers (at the flicker equivalent of a Saturday night party) and flew up here from Illinois or even Minnesota or Wisconsin. Anyway, here it was.

When we checked on 26 May 1991, the bird was still in the maples at the Brygider farm, three $\mathrm{km}$ south of Saltcoats. After some searching, with a good deal of help from Walter and Olga, we located the rare bird. It was, according to the field marks noted earlier, a Red-bellied Woodpecker, probably a young male, judging by the plumage colour on the underside. There was ample time to observe this bird in flight and later perched on a dead branch. We watched for some minutes as it preened in the sunlight. In spite of the fact I obtained no photographic record for confirmation, it is my considered opinion that, in view of the observation we made of this bird, it was, without doubt, a Red-bellied Woodpecker. After about five days the Brygiders did not see the bird again.

What a pleasant and interesting experience for all of us. 